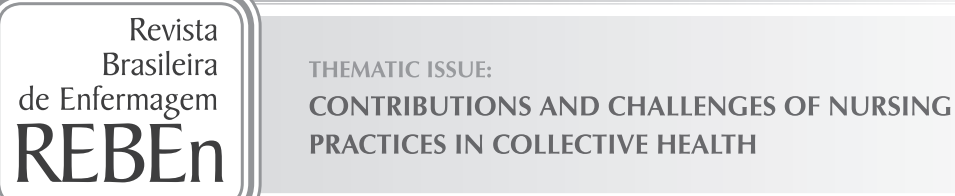

\title{
Quality of life of elderly people living with HIV/AIDS in outpatient follow-up
}

\author{
Qualidade de vida de idosos vivendo com HIV/aids em acompanhamento ambulatorial \\ Calidad de vida de ancianos viviendo con VIH/SIDA en acompañamiento ambulatorial
}

\author{
Juliano de Souza Caliari', Lilian Andreia Fleck Reinato', Daiana Patrícia Marchetti Pio', \\ Letícia Pimenta Lopes', Renata Karina Reis", Elucir Gir' \\ ' Universidade de São Paulo, Nursing School of Ribeirão Preto, \\ Postgraduate Program in Nursing. Ribeirão Preto, São Paulo, Brazil. \\ "Universidade de São Paulo, Nursing School of Ribeirão Preto, \\ Departmant of General and Specialized Nursing. Ribeirão Preto, São Paulo, Brazil.
}

How to cite this article:

Caliari JS, Reinato LAF, Pio DPM, Lopes LP, Reis RK, Gir E. Quality of life of elderly people living with HIV/AIDS in outpatient follow-up. Rev Bras Enferm [Internet]. 2018;71(Suppl 1):513-22. [Thematic Issue: Contributions and challenges of nursing practices in collective health] DOI: http://dx.doi.org/10.1590/0034-7167-2017-0127

Submission: 03-23-2017

Approval:08-09-2017

\begin{abstract}
Objective: To analyze factors related to the quality of life of elderly people living with HIV/AIDS. Method: A cross-sectional study was carried out with people aged 50 years or more in a specialized outpatient clinic. The data collection was by means of an interview. For the analysis of data and characterization of the sample, descriptive statistics and comparison tests were used. The project met the ethical requirements. Results: Participants were 81 users aged 50 to 75 years, mean age was $57.8( \pm 6.1)$ years, $71.6 \%$ of whom were men. There was a statistically significant relationship with the quality of life, the following variables: gender, children, occupation, religion, diagnosis time, HIV exposure, adverse effects, treatment interruption, viral load counts, hospitalization, dependence for daily activities and use of drugs. Conclusion: The results suggest that the quality of life deficit is related not only to physical changes, but to the anguish and stigma related to HIV/AIDS.
\end{abstract}

Descriptors: Acquired Immunodeficiency Syndrome; HIV; HIV Seropositivity; Quality of Life; HIV Infections.

\section{RESUMO}

Objetivo: Analisar os fatores relacionados com a qualidade de vida de idosos vivendo com HIV/aids. Método: Estudo transversal realizado com pessoas de idade igual ou superior a 50 anos em um ambulatório especializado. A coleta de dados foi por meio de entrevista. Para a análise dos dados e caracterização da amostra, utilizou-se da estatística descritiva e testes de comparação. O projeto atendeu às exigências éticas. Resultados: Participaram 81 usuários de 50 a 75 anos, cuja média foi $57,8( \pm 6,1)$ anos, sendo $71,6 \%$ homens. Houve relação estatisticamente significante com a qualidade de vida, as seguintes variáveis: sexo, filhos, ocupação, religião, tempo de diagnóstico, exposição ao HIV, efeitos adversos, interrupção do tratamento, contagem de carga viral, internação, dependência para atividades diárias e uso de drogas. Conclusão: Os resultados sugerem que o déficit de qualidade de vida não está ligado apenas às mudanças físicas, mas às angustias e ao estigma relacionado ao HIV/aids.

Descritores: Síndrome de Imunodeficiência Adquirida; HIV; Soropositividade para HIV; Qualidade de Vida; Infecções por HIV.

\section{RESUMEN}

Objetivo: Analizar los factores relacionados con la calidad de vida de ancianos que viven con VIH/SIDA. Método: Estudio transversal realizado con personas de edad igual o superior a 50 años en un ambulatorio especializado. La recolección de datos fue por medio de entrevista. Para el análisis de los datos y caracterización de la muestra, se utilizó la estadística descriptiva 
y pruebas de comparación. El proyecto cumplió con los requisitos éticos. Resultados: Participaron 81 usuarios de 50 a 75 años, cuya media fue 57,8 $( \pm 6,1))$ años, siendo 71,6\% hombres. Se observó una relación estadísticamente significativa con la calidad de vida, las cuales fueron: sexo, hijos, ocupación, religión, tiempo de diagnóstico, exposición al VIH, efectos adversos, interrupción del tratamiento, recuento de carga viral, internación, dependencia para actividades diarias y uso de medicamentos. Conclusión: Los resultados sugieren que el déficit de calidad de vida no está relacionado sólo a los cambios físicos, sino a las angustias y al estigma relacionado con el VIH/SIDA.

Descriptores: Síndrome de Inmunodeficiencia Adquirida; VIH; Seropositividad para el VIH; Calidad de Vida; Infecciones por VIH.

CORRESPONDING AUTHORＪuliano de Souza Caliari E-mail: julianocaliari@yahoo.com.br

\section{INTRODUCTION}

Since the beginning of the human immunodeficiency virus (HIV) epidemic, studies have been carried out evaluating the impact of this disease on the quality of life (QoL) of people affected by HIV/AIDS ${ }^{(1)}$. Thus, with advancement in treatment and with the decrease of secondary infections, such as increased survival rates and disease chronicity, understanding the factors related to better QoL has become one of the main objectives of HIV/AIDS research ${ }^{(2-3)}$.

Chronicity of AIDS was a milestone in improving the living conditions of people living with HIV/AIDS (PLHA). The increase in the time of living with HIV allowed infected individuals a greater possibility of acceptance, adaptation and conformation with the disease, and thus, to establish affective and sexual relationships, and even to improve adherence to treatment ${ }^{(4-10)}$.

With the best QoL, people started to have a longer survival, which allowed the aging of PLHA ${ }^{(10)}$. So, of the 36.7 million people living in 2015 with HIV/AIDS, 5.8 million were 50 or older $^{(1)}$. However, the possibility of a longer life is not always related to $\operatorname{good}^{(4)}$, since QOL can be affected by several factors, such as individual, age, gender, schooling, income, marital status, CD4 + T lymphocyte counts and ART use, but also by cultural factors, social and emotional, which may impact the perception of this construct ${ }^{(4-5)}$.

The search for QoL does not only end with the extension of the years of life, taking into account the meaning of living with HIV, which can represent the rupture of affective relationships, problems with sexuality and lack of social and financial resources, which may compromise the mental health, physical well-being and well-being of individuals living with $\mathrm{HIV}^{(4)}$, especially those aged 50 or over, as well as their caregivers and family members ${ }^{(1,6-7)}$. Thus, the objective of this study was to analyze the sociodemographic and clinical factors related to QoL of people aged 50 years or over living with HIV/AIDS.

\section{METHOD}

\section{Ethical aspects}

The project was approved by the Research Ethics Committee of the Passos-Minas Gerais State Higher Education Foundation (FESP-MG), meeting the ethical requirements proposed by Resolution 466/12 of the National Health Council.

\section{Design, place of study and period}

This is a cross-sectional, analytical study carried out in an outpatient clinic specialized in PLHA of the state health network, which is a reference for 18 municipalities in the southwestern region of Minas Gerais, with a record of 758 cases of PLHA in the region until the end of 2015.

\section{Population or sample: exclusion and inclusion criteria}

Participants in the study were those who were 50 years of age or older. The selection of the participants was performed by a consecutive sample, in the period between September 2014 and December 2015. The following inclusion criteria were considered: age equal or superior to 50 years; have been using antiretroviral therapy (ART) for at least six months; and be in regular clinical outpatient follow-up, monthly withdrawal of antiretroviral and attending medical appointments every three months in the unit. Exclusion criteria were: live in situations of confinement, such as prisoners, institutionalized and residents of support houses, attended at the outpatient clinic.

\section{Study protocol}

Data collection was done through an individual interview, in a private room, in the same service, guided by a survey contemplating sociodemographic variables (gender, schooling, marital status, presence of children, income, occupation, home arrangement and religion (time of diagnosis, HIV exposure, adverse effects, discontinuation after initiation of treatment, TCD4 + lymphocyte counts, viral load counts, HIV/ AIDS-related hospitalizations, comorbidities, dependence for daily activities and use of drugs). The HAT-QoL survey was used to measure the quality of life of people living with HIV/ AIDS in the last four weeks ${ }^{(8)}$, consisting of 34 items distributed in 9 categories: general function, satisfaction with life, concerns about health, financial concerns, medication concerns, HIV acceptance, concerns about confidentiality, physician confidence, and sexual function, all of which are related to a greater or lesser perception of quality of life. The answers are on a Likert scale of five points: all time ${ }^{(1)}$, most of the time ${ }^{(2)}$, part of the time ${ }^{(3)}$, few time ${ }^{(4)}$ and never ${ }^{(5)}$; so that the dimensions of the survey are measured in scores ranging from one (perceived lower quality of life) to one hundred (higher quality of life perceived).

For the calculation of the categories of the survey, the score manual proposed for the instrument was used ${ }^{(9)}$. The database 
was formatted in a Microsoft Office Excel ${ }^{\circledR}$ worksheet (Windows 2010), after double typing and validation of the data, the worksheet was exported to the IBM ${ }^{\circledR}$ SPSS statistical analysis program, version 23.0.

\section{Results analysis and statistics}

For data analysis and sample characterization, descriptive statistics were used, with simple frequency, measures of central tendency and variability. The Shapiro-Wilk test was used to evaluate the normality of the distributions, considering significance $p>0.05$; and applied the Mann-Whitney and KruskalWallis tests to analyze the difference between category means.

\section{RESULTS}

Of the total of 338 users enrolled in the service, 81 met the inclusion criteria, which were between the minimum age of 50 and the maximum of 75 years, with a mean of $57.8( \pm$ $6.1)$ and a median of 57.0 years. Of these, 31 (38.3\%) contracted HIV after 50 years. According to sociodemographic variables, $58(71.6 \%)$ were male; $37(45.7 \%)$ had one to five full years of education; $56(69.1 \%)$ are said to be married or to live together; 55 (67.9\%) reported having children; 43

Table 1 - Distribution of frequencies and percentages of people living with HIV/AIDS at a specialized outpatient clinic ( $\mathrm{n}=81$ ), according to sociodemographic variables, Passos, Minas Gerais State, Brazil, 2014 - 2015

\begin{tabular}{|c|c|c|}
\hline Sociodemographic variables & $\mathbf{n}$ & $\%$ \\
\hline \multicolumn{3}{|l|}{ Gender } \\
\hline Male & 58 & 71.6 \\
\hline Female & 23 & 28.4 \\
\hline \multicolumn{3}{|l|}{ Education (finished years) } \\
\hline 0 & 10 & 12.3 \\
\hline $1|-| 5$ & 37 & 45.7 \\
\hline$\geq 6$ & 34 & 42.0 \\
\hline \multicolumn{3}{|l|}{ Marital status } \\
\hline Single, widowed and divorced & 25 & 30.9 \\
\hline Married and living together & 56 & 69.1 \\
\hline \multicolumn{3}{|l|}{ Children } \\
\hline No & 26 & 32.1 \\
\hline Yes & 55 & 67.9 \\
\hline \multicolumn{3}{|l|}{$*$ Income $(\mathrm{MW}=$ minimum wage $)$} \\
\hline$\leq 1 \mathrm{MW}$ & 38 & 46.9 \\
\hline$>1 \mathrm{MW}$ & 43 & 53.1 \\
\hline \multicolumn{3}{|l|}{ Occupation } \\
\hline No occupation & 5 & 6.2 \\
\hline Withdrawn/retired & 46 & 56.8 \\
\hline Employed & 30 & 37.0 \\
\hline \multicolumn{3}{|l|}{ Household arrengment } \\
\hline Alone & 21 & 25.9 \\
\hline Accompanied & 60 & 74.1 \\
\hline \multicolumn{3}{|l|}{ Religion practicing } \\
\hline Yes & 60 & 74.1 \\
\hline No & 21 & 25.9 \\
\hline
\end{tabular}

Note: *Minimum wage in force during the survey period was $R \$ 724.00$ (US\$ 224.00) in 2014 and $R \$ 788.00$ (US\$241.00) in 2015.
$(53.1 \%)$ received more than one minimum wage per month; $46(56.8 \%)$ reported being retired or retired; $60(74.1 \%)$ were accompanied and $60(74.1 \%)$ mentioned that they were religion practicing.

Regarding the clinical variables, the 29 (35.8\%) participants who lived with the diagnosis of HIV infection for a period longer than 10.1 years were the most important; the $62(76.5 \%)$ who had sexual exposure; the $61(76.5 \%)$ who had no adverse effects with the treatment; the $70(86.4 \%)$ who reported never having stopped using antiretroviral therapy (ART); the $62(76.5 \%)$ had CD4 + lymphocyte counts above $350 \mathrm{~mm} 3 / \mathrm{blood}$; the $64(79.0 \%)$ with undetectable viral load; the $51(63.0 \%)$ had no history of hospitalization for HIV/AIDS complications; the 61 (75.3\%) who did not mention the presence of comorbidities; the 77 (95.1\%) who did not need help for activities of daily living (DLA); and the $65(80.2 \%)$ participants who denied the use of any legal or illegal drug.

Table 2 - Distribution of frequencies and percentages of people living with HIV/AIDS from a specialized outpatient clinic ( $\mathrm{n}=81$ ), according to the clinical variables, Passos, Minas Gerais State, Brazil, 2014 - 2015

\begin{tabular}{|c|c|c|}
\hline Clinical variables & $\mathbf{n}$ & $\%$ \\
\hline \multicolumn{3}{|l|}{ HIV diagnostic time (years) } \\
\hline$\leq 5$ & 14 & 29.7 \\
\hline $5,1|-| 10$ & 28 & 34.6 \\
\hline$\geq 10,1$ & 29 & 35.8 \\
\hline \multicolumn{3}{|l|}{ Exposure to HIV } \\
\hline Sexual & 62 & 76.5 \\
\hline Non sexual & 10 & 12.4 \\
\hline Do not know & 9 & 11.1 \\
\hline \multicolumn{3}{|l|}{ Adverse effects } \\
\hline No & 61 & 75.3 \\
\hline Yes & 20 & 24.7 \\
\hline \multicolumn{3}{|l|}{ Interruption of ART } \\
\hline No & 70 & 86.4 \\
\hline Yes & 11 & 13.6 \\
\hline \multicolumn{3}{|l|}{ TCD4 + counts } \\
\hline$\leq 350 \mathrm{~mm} 3 / \mathrm{blood}$ & 19 & 23.5 \\
\hline$>350 \mathrm{~mm} 3 / \mathrm{blood}$ & 62 & 76.5 \\
\hline \multicolumn{3}{|l|}{ Viral load counts } \\
\hline$<50$ copies/ml (undetectable) & 64 & 79.0 \\
\hline$\geq 50$ copies/ml (detectable) & 17 & 21.0 \\
\hline \multicolumn{3}{|l|}{ Hospitalizations/reason HIV/AIDS } \\
\hline No & 51 & 63.0 \\
\hline Yes & 30 & 37.0 \\
\hline \multicolumn{3}{|l|}{ Comorbities } \\
\hline No & 61 & 75.3 \\
\hline Yes & 20 & 24.7 \\
\hline \multicolumn{3}{|l|}{ Dependence for DLA } \\
\hline No & 77 & 95.1 \\
\hline Yes & 4 & 4.9 \\
\hline \multicolumn{3}{|l|}{ Use of drugs (legal and illegal) } \\
\hline No & 65 & 80.2 \\
\hline Yes & 16 & 19.8 \\
\hline
\end{tabular}

Note: ART - antiretroviral therapy; TCD4 + - T lymphocyte; DLA - daily life activities 
Table 3 - Distribution of HAT-QoL Survey scores, applied to people living with HIV/AIDS at a specialized outpatient clinic (n = 81), Passos, Minas Gerais State, Brazil, 2014-2015

\begin{tabular}{|c|c|c|c|c|c|c|}
\hline Score - categories & Number of items & Minimum & Maximum & Median & Mean & Standard Deviation \\
\hline General function & 6 & 16.7 & 100.0 & 67.1 & 75.0 & 27.1 \\
\hline Satisfaction with life & 4 & 6.3 & 100.0 & 68.6 & 75.0 & 31.6 \\
\hline Concerns about health & 4 & 6.3 & 100.0 & 66.8 & 75.0 & 33.0 \\
\hline Financial Concerns & 3 & 0.0 & 100.0 & 48.5 & 50.0 & 38.5 \\
\hline Medication Concerns & 5 & 0.0 & 100.0 & 86.2 & 100.0 & 20.7 \\
\hline HIVAcceptance & 2 & 0.0 & 100.0 & 70.6 & 75.0 & 34.0 \\
\hline Concerns about secrecy & 5 & 0.0 & 100.0 & 44.6 & 40.0 & 37.6 \\
\hline Professional confidence & 3 & 0.0 & 100.0 & 88.5 & 100.0 & 23.5 \\
\hline Sexual function & 2 & 0.0 & 100.0 & 55.0 & 50.0 & 39.6 \\
\hline
\end{tabular}

In the descriptive statistics of the QoL survey, the highest median and average values were concentrated in the areas of "professional confidence" and "medication concerns", while the lowest median and average values were in the "financial concerns" and "concerns about secrecy"(Table 3).

The relationship between the sociodemographic variables and the categories of the quality of life survey were statistically significant: gender with the "health concern" categories ( $p=0.029$ ) and "professional confidence" ( $p$ $=0.043$ ), with the highest distribution of males and males in the "male" category; with the "children" variable in the "concerns about health" category ( $p=0.026)$, with a higher mean and median values for the absence of children and with the category "concerns about secrecy" ( $p=0.024)$ and median in the "children" category; occupation of the participants with the category "concerns about secrecy" $(p=$ $0.043)$, especially the "withdrawn or retired" category; $(p=$ $0.039)$ and "satisfaction with life" ( $p=0.045)$ with a higher distribution of averages and medians in the "presence of religious practice" category and the "concerns about secrecy" category ( $p=0.030$ ), especially in the "absence of religious practice" category, with a higher mean and median value.

In the distribution of the mean scores with the clinical variables, it was found that the variable "HIV diagnostic time" with the "sexual function" category ( $p=0.014$ ) was statistically significant, especially for the category "time greater than 10 years" with the highest mean and median values. The variable "exposure to HIV" with the category "satisfaction with life" ( $p=0.006)$ and "financial concerns" ( $p=0.006)$ with higher mean and median values in the category do not know, and in the category "professional confidence" ( $p=0.004)$ with the highest values in the "sexual" category. The relation of adverse effects with the "general function" categories ( $p=0.037)$, "medication concerns" ( $p$ $=0.018)$ and "professional confidence" $(p=0046)$ with the distribution of the highest averages and medians in the category "no". In the discontinuation of antiretroviral therapy, the significance of the "medication concerns" ( $p=0.047$ ) and "sexual function" categories ( $p=0.005$ ) with higher mean and median values in the "no" in the "HIV acceptance" categories ( $p=0.005)$ and "concerns about secrecy" $(p=0.026)$ in the "yes" category. The viral load counts with the category "satisfaction with life" ( $p=0.031$ ) with the highest values in the "less than 50 copies/ml" category. The "satisfaction with life" category $(p=0.045)$ with the highest mean and median values in the "no" category and the "concerns about secrecy" category ( $p=0.008)$, with emphasis on the "yes" category. The relation of the variable "daily life activities (DLA)" with the "general function" category $(p=0.001)$ and "concerns about health" ( $p=0.038)$ with higher averages and medians in the "no" category. The use of licit and illicit drugs with the category "professional confidence" ( $p=0.042)$, with emphasis on the "yes" category, with higher mean and median values. 
Table 4 - Distribution of the HAT-QoL Survey scores, applied to people living with HIV/AIDS in a specialized outpatient clinic $(\mathrm{n}=81)$, according to sociodemographic variables, Passos - Minas Gerais State, 2014 - 2015

\begin{tabular}{|c|c|c|c|c|c|c|c|c|c|c|c|c|c|c|c|c|c|c|}
\hline \multirow{3}{*}{ Sociodemographic Variables } & \multicolumn{14}{|c|}{ HAT-QoL Survey } & & & & \\
\hline & \multicolumn{2}{|c|}{$\begin{array}{c}\text { General } \\
\text { funcation }\end{array}$} & \multicolumn{2}{|c|}{$\begin{array}{l}\text { Satisfaction with } \\
\text { life }\end{array}$} & \multicolumn{2}{|c|}{$\begin{array}{c}\text { Concerns about } \\
\text { health }\end{array}$} & \multicolumn{2}{|c|}{$\begin{array}{l}\text { Financial } \\
\text { concerns }\end{array}$} & \multicolumn{2}{|c|}{$\begin{array}{l}\text { Medication } \\
\text { concern }\end{array}$} & \multicolumn{2}{|c|}{ HIV acceptance } & \multicolumn{2}{|c|}{$\begin{array}{c}\text { Concern about } \\
\text { secrecy }\end{array}$} & \multicolumn{2}{|c|}{$\begin{array}{l}\text { Professional } \\
\text { confidence }\end{array}$} & \multicolumn{2}{|c|}{$\begin{array}{c}\text { Sexual } \\
\text { function }\end{array}$} \\
\hline & *Md & $* M$ & *Md & $* M$ & *Md & ${ }^{*} \mathbf{M}$ & $* \mathrm{Md}$ & $* \mathbf{M}$ & $* \mathrm{Md}$ & $* M$ & ${ }^{*} \mathbf{M d}$ & ${ }^{*} \mathbf{M}$ & $* \mathrm{Md}$ & $* \mathbf{M}$ & ${ }^{*} \mathrm{Md}$ & $* M$ & $* \mathbf{M d}$ & $* M$ \\
\hline \multicolumn{19}{|l|}{ Gender $^{(b)}$} \\
\hline Male & 75.0 & 67.6 & 75.0 & 69.1 & 81.2 & 71.1 & 62.5 & 49.7 & 95.0 & 85.5 & 87.5 & 71.5 & 37.5 & 42.6 & 100.0 & 92.5 & 75.0 & 59.6 \\
\hline Female & 62.5 & 65.9 & 75.0 & 67.1 & 50.0 & 52.4 & 33.3 & 45.3 & 100.0 & 87.8 & 50.0 & 64.7 & 40.0 & 46.1 & 98.0 & 78.3 & 25.0 & 42.9 \\
\hline$p$ value & \multicolumn{2}{|c|}{0.987} & \multicolumn{2}{|c|}{0.953} & \multicolumn{2}{|c|}{0.029} & \multicolumn{2}{|c|}{0.734} & \multicolumn{2}{|c|}{0.698} & \multicolumn{2}{|c|}{0.228} & \multicolumn{2}{|c|}{0.560} & \multicolumn{2}{|c|}{0.043} & \multicolumn{2}{|c|}{0.081} \\
\hline Education (finished years) (a) $^{(a)}$ & & & & & & & & & & & & & & & & & & \\
\hline 0 & 50.0 & 56.7 & 62.5 & 65.6 & 21.9 & 42.1 & 0.0 & 35.8 & 100.0 & 91.5 & 100.0 & 87.5 & 77.5 & 56.5 & 100.0 & 97.5 & 75.0 & 57.5 \\
\hline $1|-| 5$ & 75.0 & 67.3 & 75.0 & 67.2 & 75.0 & 69.9 & 50.0 & 51.1 & 95.0 & 89.6 & 75.0 & 71.3 & 40.0 & 47.8 & 100.0 & 91.7 & 50.0 & 53.4 \\
\hline$\geq 6$ & 81.3 & 70.0 & 81.3 & 71.0 & 81.3 & 68.0 & 58.3 & 49.3 & 97.5 & 80.8 & 75.0 & 62.5 & 22.5 & 35.3 & 100.0 & 82.4 & 50.0 & 56.0 \\
\hline$p$ value & & 96 & & 42 & & & & 34 & 0.7 & 27 & 0.1 & & 0. & & 0.3 & & 0.8 & 42 \\
\hline Marital status ${ }^{(a)}$ & & & & & & & & & & & & & & & & & & \\
\hline Single, widowed and divorced & 70.8 & 65.7 & 75.0 & 64.4 & 75.0 & 63.6 & 33.3 & 41.4 & 90.0 & 78.2 & 75.0 & 64.8 & 35.0 & 40.7 & 100.0 & 88.4 & 75.0 & 58.7 \\
\hline Married and living together & 68.7 & 63.8 & 75.0 & 65.8 & 59.4 & 56.0 & 25.0 & 38.8 & 85.0 & 77.5 & 81.3 & 66.9 & 40.0 & 40.0 & 100.0 & 86.6 & 75.0 & 62.6 \\
\hline$p$ value & & 67 & & 98 & & & & 22 & 0.8 & 399 & 0.4 & & 0.8 & & 0.6 & & 0.3 & 50 \\
\hline Children $^{(b)}$ & & & & & & & & & & & & & & & & & & \\
\hline No & 83.3 & 74.1 & 75.0 & 70.9 & 87.5 & 79.8 & 66.6 & 55.1 & 97.5 & 82.6 & 75.0 & 68.7 & 20.0 & 29.6 & 100.0 & 94.2 & 75.0 & 67.3 \\
\hline Yes & 66.6 & 63.7 & 75.0 & 67.5 & 68.7 & 59.2 & 33.3 & 45.3 & 100.0 & 83.5 & 87.5 & 70.0 & 45.0 & 50.2 & 100.0 & 85.7 & 50.0 & 49.0 \\
\hline$p$ value & 0.1 & 41 & & 305 & & & 0.3 & 41 & 0.8 & 337 & 0.6 & & & & 0.6 & & 0.0 & \\
\hline Income $^{(b)}$ & & & & & & & & & & & & & & & & & & \\
\hline$\leq 1 \mathrm{MW}$ & 66.7 & 66.4 & 75.0 & 68.4 & 75.0 & 67.3 & 41.6 & 44.0 & 100.0 & 85.1 & 75.0 & 72.0 & 32.5 & 41.8 & 75.0 & 57.2 & 100.0 & 90.4 \\
\hline$>1 \mathrm{MW}$ & 75.0 & 67.7 & 75.0 & 68.7 & 75.0 & 64.5 & 58.3 & 52.3 & 95.0 & 87.0 & 75.0 & 67.4 & 40.0 & 45.2 & 50.0 & 52.9 & 100.0 & 86.8 \\
\hline$p$ value & 1. & 00 & & 58 & & & 0.3 & 50 & 0.6 & 15 & 0.8 & & 0. & & 0.9 & & 0.6 & 66 \\
\hline Occupation $^{(a)}$ & & & & & & & & & & & & & & & & & & \\
\hline No occupation & 50.0 & 67.5 & 93.7 & 81.3 & 50.0 & 60.0 & 16.7 & 46.7 & 100.0 & 92.0 & 37.5 & 55.0 & 5.0 & 9.0 & 100.0 & 85.5 & 25.0 & 45.0 \\
\hline Withdrawn/retired & 72.9 & 68.8 & 75.0 & 66.8 & 75.0 & 65.6 & 54.2 & 51.4 & 97.5 & 89.7 & 81.3 & 73.6 & 50.0 & 51.3 & 100.0 & 91.1 & 50.0 & 52.4 \\
\hline Employed & 75.0 & 64.4 & 75.0 & 69.2 & 81.3 & 67.0 & 45.8 & 44.2 & 85.0 & 79.8 & 75.0 & 65.8 & 25.0 & 37.7 & 100.0 & 85.5 & 75.0 & 60.4 \\
\hline$p$ value & $0 . \varepsilon$ & 34 & & 361 & & & 0.6 & 27 & 0.2 & 94 & 0.4 & & & & 0.3 & & 0.5 & 99 \\
\hline Household arrengments $^{(b)}$ & & & & & & & & & & & & & & & & & & \\
\hline Alone & 83.3 & 76.1 & 81.2 & 76.7 & 75.0 & 71.7 & 50.0 & 46.8 & 100.0 & 89.0 & 75.0 & 73.8 & 20.0 & 39.2 & 100.0 & 94.0 & 75.0 & 65.4 \\
\hline Accompanied & 66.6 & 63.9 & 75.0 & 65.7 & 71.8 & 63.7 & 50.0 & 49.0 & 95.0 & 85.1 & 75.0 & 68.1 & 40.0 & 45.2 & 100.0 & 86.5 & 50.0 & 51.2 \\
\hline$p$ value & 0.0 & 85 & & 60 & & & 0.8 & 36 & 0.3 & 64 & 0.7 & & & & 0.0 & & 0.0 & 61 \\
\hline Religion practicing $^{(b)}$ & & & & & & & & & & & & & & & & & & \\
\hline Yes & 81.3 & 70.4 & 75.0 & 73.2 & 75.0 & 73.2 & 41.7 & 46.3 & 100.0 & 86.7 & 75.0 & 70.4 & 30.0 & 38.8 & 100.0 & 89.3 & 75.0 & 58.8 \\
\hline No & 66.7 & 57.7 & 62.5 & 55.4 & 62.5 & 55.4 & 66.7 & 54.7 & 95.0 & 84.7 & 75.0 & 67.3 & 60.0 & 57.4 & 100.0 & 86.1 & 25.0 & 44.0 \\
\hline$p$ value & 0.0 & 39 & & 45 & & & 0.3 & 65 & 0.3 & 01 & 0.8 & & & 30 & 0.1 & & 0.2 & 10 \\
\hline
\end{tabular}

Note: ${ }^{*} M d=$ median; $M=$ mean; (a) Kruskal-Wallis test; (b) Mann-Whitney Test; $M W$ - minimum wage. 


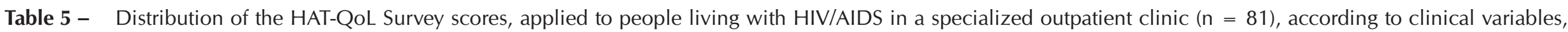
Passos, Minas Gerais State, Brazil, 2014-2015

\begin{tabular}{|c|c|c|c|c|c|c|c|c|c|c|c|c|c|c|c|c|c|c|}
\hline \multicolumn{19}{|c|}{ Questionário HAT-QoL } \\
\hline \multirow[t]{2}{*}{ Sociodemographic Variables } & \multicolumn{2}{|c|}{$\begin{array}{c}\text { General } \\
\text { funcation }\end{array}$} & \multicolumn{2}{|c|}{$\begin{array}{l}\text { Satisfaction } \\
\text { with life }\end{array}$} & \multicolumn{2}{|c|}{$\begin{array}{l}\text { Concerns about } \\
\text { health }\end{array}$} & \multicolumn{2}{|c|}{$\begin{array}{l}\text { Financial } \\
\text { concerns }\end{array}$} & \multicolumn{2}{|c|}{$\begin{array}{l}\text { Medication } \\
\text { concern }\end{array}$} & \multicolumn{2}{|c|}{ HIV acceptance } & \multicolumn{2}{|c|}{$\begin{array}{c}\text { Concern about } \\
\text { secrecy }\end{array}$} & \multicolumn{2}{|c|}{$\begin{array}{l}\text { Professional } \\
\text { confidence }\end{array}$} & \multicolumn{2}{|c|}{ Sexual function } \\
\hline & ${ }^{*} \mathrm{Md}$ & $* M$ & ${ }^{*} \mathrm{Md}$ & $* \mathrm{M}$ & $*$ Md & $* \mathbf{M}$ & $* \mathrm{Md}$ & $* M$ & $* \mathrm{Md}$ & $* M$ & $* \mathbf{M d}$ & $* \mathbf{M}$ & $* M d$ & $* \mathbf{M}$ & $* M d$ & $* \mathbf{M}$ & $* \mathrm{Md}$ & $* \mathbf{M}$ \\
\hline \multicolumn{19}{|l|}{ HIV diagnostic time (years)(a) } \\
\hline$\leq 5$ & 64.6 & 65.6 & 75.0 & 62.0 & 81.3 & 71.0 & 58.3 & 47.2 & 97.5 & 86.7 & 75.0 & 64.6 & 35.0 & 41.3 & 100.0 & 89.2 & 74.0 & 62.5 \\
\hline $5.1|-| 10$ & 68.8 & 63.5 & 75.0 & 69.2 & 59.4 & 58.5 & 41.7 & 43.2 & 92.5 & 86.4 & 93.8 & 73.2 & 27.5 & 35.2 & 100.0 & 86.3 & 25.0 & 38.4 \\
\hline$\geq 10.1$ & 83.3 & 71.8 & 81.3 & 73.5 & 75.0 & 68.7 & 75.0 & 54.6 & 100.0 & 85.5 & 75.0 & 70.3 & 60.0 & 53.8 & 100.0 & 89.9 & 75.0 & 63.8 \\
\hline$p$ value & \multicolumn{2}{|c|}{0.504} & \multicolumn{2}{|c|}{0.176} & \multicolumn{2}{|c|}{0.414} & \multicolumn{2}{|c|}{0.626} & \multicolumn{2}{|c|}{0.592} & & & 0. & & 0. & & 0.0 & \\
\hline HIV exposure $^{(a)}$ & & & & & & & & & & & & & & & & & & \\
\hline Sexual & 68.7 & 64.7 & 75.0 & 64.5 & 71.4 & 61.0 & 25.0 & 36.7 & 90.0 & 78.9 & 75.0 & 64.6 & 35.0 & 39.3 & 100.0 & 89.9 & 62.5 & 57.4 \\
\hline Non sexual & 50.0 & 57.5 & 56.3 & 55.4 & 50.0 & 56.6 & 33.3 & 48.8 & 80.0 & 75.5 & 50.0 & 61.2 & 40.0 & 43.1 & 97.0 & 70.7 & 99.0 & 69.0 \\
\hline Do not know & 83.3 & 74.5 & 99.0 & 79.2 & 75.0 & 59.3 & 66.7 & 57.7 & 85.0 & 72.9 & 99.0 & 78.7 & 40.0 & 45.9 & 98.0 & 87.8 & 87.5 & 73.1 \\
\hline$p$ value & & & & & & & & & 0.1 & 59 & 0. & & & & & & 0.0 & \\
\hline Adverse effects ${ }^{(b)}$ & & & & & & & & & & & & & & & & & & \\
\hline No & 79.1 & 69.0 & 75.0 & 69.9 & 75.0 & 65.8 & 50.0 & 48.7 & 100.0 & 87.6 & 75.0 & 70.0 & 40.0 & 43.4 & 100.0 & 90.2 & 75.0 & 57.9 \\
\hline Yes & 54.1 & 53.3 & 62.5 & 58.7 & 87.5 & 65.6 & 33.3 & 46.6 & 67.5 & 75.5 & 81.2 & 66.2 & 30.0 & 45.0 & 87.5 & 75.8 & 25.0 & 33.7 \\
\hline$p$ value & & & & & & & & & 0.0 & 18 & 0 & & 0 & & & & 0.0 & \\
\hline Interruption of $A R T^{(b)}$ & & & & & & & & & & & & & & & & & & \\
\hline No & 75.0 & 68.8 & 75.0 & 70.0 & 75.0 & 66.4 & 50.0 & 48.0 & 100.0 & 87.1 & 75.0 & 65.8 & 35.0 & 39.9 & 100.0 & 90.2 & 75.0 & 60.0 \\
\hline Yes & 50.0 & 56.4 & 50.0 & 59.6 & 68.7 & 61.9 & 50.0 & 50.7 & 75.0 & 80.0 & 99.0 & 3.1 & 80.0 & 67.3 & 100.0 & 77.2 & 25.0 & 22.7 \\
\hline$p$ value & & & & & & & & & 0.0 & 47 & 0. & & 0. & & & & 0.0 & \\
\hline TCD4 + counts $(\mathrm{mm} 3 / \mathrm{blood})^{(\mathrm{b})}$ & & & & & & & & & & & & & & & & & & \\
\hline$\leq 350$ & 66.7 & 63.0 & 75.0 & 60.0 & 56.3 & 53.5 & 25.0 & 33.3 & 80.0 & 73.0 & 75.0 & 62.7 & 40.0 & 45.9 & 100.0 & 85.4 & 75.0 & 64.5 \\
\hline$>350$ & 70.8 & 65.5 & 75.0 & 66.6 & 75.0 & 62.5 & 33.3 & 42.5 & 90.0 & 79.4 & 75.0 & 66.6 & 35.0 & 38.7 & 100.0 & 88.4 & 75.0 & 59.0 \\
\hline$p$ value & & & & & & & & & 0.0 & 52 & 0. & & 0. & & & & 0.4 & \\
\hline Viral load counts (copies/ml) (b) & & & & & & & & & & & & & & & & & & \\
\hline$<50$ & 83.3 & 68.8 & 81.3 & 71.7 & 75.0 & 66.8 & 54.2 & 50.8 & 100.0 & 86.6 & 75.0 & 67.6 & 40.0 & 43.4 & 100.0 & 89.5 & 75.0 & 57.8 \\
\hline$\geq 50$ & 66.7 & 60.8 & 62.5 & 57.0 & 75.0 & 62.1 & 25.0 & 39.7 & 90.0 & 84.4 & 99.0 & 77.2 & 40.0 & 44.7 & 100.0 & 84.8 & 25.0 & 44.1 \\
\hline$p$ value & & & & & & & & & 0.1 & 81 & 0. & & 0. & & & & 0.2 & \\
\hline Hospitalizations/ HIV/AIDS ${ }^{(b)}$ & & & & & & & & & & & & & & & & & & \\
\hline No & 79.1 & 70.6 & 75.0 & 76.1 & 75.0 & 64.4 & 41.6 & 43.6 & 100.0 & 89.1 & 75.0 & 71.0 & 20.0 & 35.0 & 100.0 & 92.0 & 62.5 & 55.1 \\
\hline Yes & 56.2 & 61.3 & 56.3 & 55.8 & 84.3 & 68.1 & 70.8 & 56.6 & 95.0 & 81.1 & 75.0 & 67.0 & 60.0 & 58.0 & 100.0 & 82.0 & 50.0 & 54.6 \\
\hline$p$ value & & & & & & & & & 0.2 & 48 & 0. & & & & & & 0.5 & \\
\hline Comorbities $^{(b)}$ & & & & & & & & & & & & & & & & & & \\
\hline No & 75.0 & 65.4 & 75.0 & 70.0 & 68.7 & 63.1 & 50.0 & 47.9 & 95.0 & 84.0 & 75.0 & 67.4 & 35.0 & 41.1 & 100.0 & 87.4 & 50.0 & 54.9 \\
\hline Yes & 72.9 & 72.5 & 65.6 & 64.0 & 96.9 & 74.0 & 50.0 & 50.0 & 100.0 & 92.7 & 87.5 & 76.3 & 52.5 & 51.3 & 100.0 & 91.7 & 56.3 & 55.0 \\
\hline$p$ value & & & & & & & & & 0.1 & 31 & 0. & & & & & & 0.9 & \\
\hline Dependence for $\mathrm{DLA}^{(\mathrm{b})}$ & & & & & & & & & & & & & & & & & & \\
\hline No & 75.0 & 69.3 & 75.0 & 69.8 & 75.0 & 67.5 & 50.0 & 49.4 & 100.0 & 86.1 & 75.0 & 68.7 & 40.0 & 42.5 & 100.0 & 88.4 & 62.5 & 56.5 \\
\hline Yes & 25.0 & 25.0 & 43.7 & 43.7 & 28.1 & 34.4 & 12.5 & 29.2 & 85.0 & 86.3 & 99.0 & 87.5 & 80.0 & 65.0 & 100.0 & 89.6 & 12.5 & 25.0 \\
\hline$p$ value & 0 . & & & & & & & & 0.5 & 77 & 0. & & & & & & 0.1 & \\
\hline Use of drugs ${ }^{(b)}$ & & & & & & & & & & & & & & & & & & \\
\hline No & 75.0 & 69.0 & 75.0 & 68.3 & 75.0 & 67.9 & 50.0 & 50.1 & 100.0 & 87.4 & 75.0 & 71.7 & 40.0 & 42.7 & 98.0 & 86.0 & 75.0 & 58.5 \\
\hline Yes & 56.2 & 59.4 & 75.0 & 69.9 & 50.0 & 57.0 & 33.3 & 41.6 & 75.0 & 81.3 & 75.0 & 60.9 & 37.5 & 47.5 & 100.0 & 98.4 & 25.0 & 40.6 \\
\hline$p$ value & & & & & & & & & 0.1 & 82 & 0. & & 0. & & & & 0.1 & \\
\hline
\end{tabular}

Note: * Md = median; $M=$ mean; (a)Kruskal-Wallis test; (b)Mann-Whitney test; ART - antiretroviral therapy; TCD4 + - T lymphocytes; DLA - daily life activities 


\section{DISCUSSION}

The characteristics found in this population were similar to those of other national and international studies with PLHA aged 50 years or older, that is, predominantly men ${ }^{(6-7,10)}$ living married or in the same family ${ }^{(7)}$, retired ${ }^{(6)}$, low schooling and income $^{(6-7,10)}$, with a HIV diagnostic time over 10 years $^{(6,10)}$, sexual exposure(6), CD4 counts above 350/mm3 $3^{(6)}$ and absence of hospitalizations due to HIV/AIDS complications and presence of comorbidities ${ }^{(6-7)}$.

The participants in this study had the highest mean scores of HAT-Qol categories, which were: "professional confidence" and "medication concerns"; and the lowest scores in the areas of "financial concern" and "concerns about secrecy". These results were similar to those found in other national studies carried out in São Paulo(6) and João Pessoa (Paraíba) ${ }^{(9)}$, with people living with HIV/AIDS aged 50 or over who were undergoing outpatient follow- and to another study with elderly people in Switzerland ${ }^{(10)}$, with people of different ages living with HIV/AIDS in Brazil(11).

HIV infection can have many impacts on people's lives. Thus, confronting a new condition, coupled with the unique difficulties that the serological condition presents to the individual's life, has been one of the challenges faced by people living with HIV/AIDS, especially those aged 50 or over ${ }^{(1,6,10-11)}$.

The relationship of the best quality of life scores in the categories presented may be related to the attention and respect with which the health team attended the patients, favoring trust, the bond with the service and the adherence of the drug therapy ${ }^{(6,9,11)}$. Since the non-attendance or exclusionary behavior of health professionals with users living with HIV/AIDS are pointed out in the literature as barriers, which can negatively impact the life of individuals, favoring the disruption with the unit and the low adherence to the use of $\operatorname{ART}^{(1,10,12)}$.

The financial concern, pointed out by the participants, confirms results from other studies ${ }^{(6,10)}$, in which low incomes are negatively associated with quality of life evaluation, being a barrier to the maintenance of basic housing, food, health, education and transportation, which directly compromises the general health of people ${ }^{(6,11)}$.

The relationship of low quality of life and concern with identified secrecy may be related to fears of non-acceptance, feelings of guilt and shame attached to the negative image of HIV, which can significantly impact on increased anxiety, depression and death wish of PLHA ${ }^{(1,6,10-11)}$.

In the analysis of the sociodemographic and clinical variables with the QoL survey, it was found that in the variable "gender", the "male" category had the highest mean values of scores in the "concerns about health" and "professional confidence" categories. This can be confirmed by other national studies $^{(9,11)}$, which show the importance of the relationship of trust with the health professional to increase adherence to clinical follow-up, especially for men over 50 years.

Regarding the relationship between the genders, it can be observed that the low QoL associated with the woman's figure can also be confirmed by other studies ${ }^{(3,13)}$, which show that the lower QoL of women is related to the higher proportion of women in work domestic and unpaid occupations when compared to men, as well as cultural and gender aspects that limit the autonomy of women to social participation ${ }^{(3,13)}$, in addition to the differences marked by religious repression and the limitation of access to leisure ${ }^{(5)}$.

Regarding the children, although the diagnosis of the infection brings the fear of interrupting family projects negatively affecting the QoL of fathers and mothers, in Africa many individuals who have children adhere to the treatment and face the disease, in an attempt to maintain the projects of paternity and motherhood, thus maintaining the role of public life $\mathrm{e}^{(14)}$.

However, the presence of children can generate many future concerns related to concerns about health, which, coupled with the fear of not being able to maintain employment and income, has negatively impacted the QoL of many parents living with HIV/AIDS ${ }^{(15)}$.

As for the variable "occupation" with the category "concerns about secrecy", it is observed that the condition of being away or retired, can give people psychological well-being, because they no longer have to return to work or are taken to seek new employment because of stress and confrontations related to disclosure of their HIV status to their employers and colleagues $^{(15)}$; and also the receipt of monthly salary in addition to providing the purchasing power of necessary goods, contributes to family expenses and provides more autonomy ${ }^{(6)}$.

According to the practicing religion, the increase in QoL in the "general function" and "satisfaction with life" categories may be related to the role of religion as a source of support and hope in coping with problems ${ }^{(16)}$. However, the risk of disclosure of the diagnostic condition may reinforce HIV as a sin, increasing responsibility for the acts and guilt for infection $^{(1,15)}$.Closing the remoteness of many people from religious participation, hindering the relationship with God, by feeling of revolt with the serological condition, because they believe that the disease is a divine punishment ${ }^{(4,17)}$.

For the HIV diagnostic time, it was noticed that the increase in the time of HIV infection would be related to the average increase in QoL, which can be justified by the increased experience of living and living with HIV, once that, although people see HIV/AIDS as a problem, over time the infection is seen as a learning situation ${ }^{(6,18)}$ and may no longer adversely affect affective and sexual relationships.

In a cross-sectional study carried out in the country, the shortest time to diagnose infection was related to the worst scores in all categories of quality of life $\mathrm{e}^{(5)}$, with the passage of time for the diagnosis of infection necessary for the process of conformation and acceptance of the disease, as well as the new dynamics of social relationships ${ }^{(18)}$.

Regarding HIV exposure, the increase in the mean QoL score related to sexual exposure in the field of "professional confidence" may be related to the relationship of trust established between the health professional and the patient, so that the reception professional relationship can lead users to spontaneous search by health units in order to share their doubts and obtain information to maintain life habits and even reestablish sexual partnerships ${ }^{(19)}$. On the other hand, the higher values of the average quality of life score in the category "do 
not know or are unaware of HIV exposure" may be linked to the feeling of victimization, so that not knowing about HIV exposure can lead to decreased guilt feelings ${ }^{(20-21)}$, "relieving" the burden of HIV infection.

In the relation of the variable adverse effect with the categories of quality of life, the "no" category was highlighted, indicative of absence of adverse effects, which corroborates a prospective cohort study conducted in Uganda, where adverse effects had a negative influence on the treatment, especially in drug users, which had a great impact on the perception of PLHA quality of life ${ }^{(22)}$, and the adverse effects could be related to changes in the body, affecting the psychosocial well-being, the self-esteem of the people and the activities ${ }^{(23)}$.

Regarding the interruption of ART, the significant results were related to the increase in the quality of life associated with adherence to the treatment, which confirms a cross-sectional study carried out in China, which, in addition to the positive relation with the use of the antiretroviral, identified that the QoL little was related to the duration of treatment, but very much to the fact that people accept and maintain adherence to $\mathrm{it}^{(24)}$. Concerning non-adherence to treatment, it was observed that QoL was linked to the fear of diagnostic disclosure for other people and to the difficulties of accepting the new condition, and non-adherence to therapy was seen as an important alternative to maintaining confidentiality ${ }^{(25)}$.

The undetectable viral load was also related to the mean increase in QoL, which can be justified by the direct relation of this indicator with the absence of secondary infections, the decrease of the hospitalizations and the improvement of the general health status of the people, impacting even the fall of hospitalizations related to $\operatorname{HIV} / A I D S^{(5,22)}$.

Thus, although the improvement of the patients is related to the reduction of hospitalizations, there are cases in which hospitalization, even increasing the exposure of the patients' diagnosis, can lead to an increase in QoL, since it is linked to the specialized treatment of people with a history of low immunity, opportunistic infections, drug intolerance, cardiovascular disorders, hepatic impairment and neurological disorders, as shown in a multicenter cohort study conducted in Brazil and France ${ }^{(26)}$.

According to the dependence for daily life activities with QoL, it can be seen that the best satisfaction of the participants comes from the absence of dependence to perform daily life activities, which corroborates a national cross-sectional study developed in a hospital infectology outpatient clinic in which the lowest means of the QoL categories were related to changes in mobility, dependence for medication and treatment, work ability, which, related to the disease, were directly related to activities of daily living ${ }^{(15)}$.

As for drug use, it was verified that the use of the drug was linked to the increase in QoL, with higher mean and median values in the professional confidence category. Such a relationship, although very associated with low adherence to treatment, fear of toxicity, and an increase in the adverse effects of ART ${ }^{(24)}$, in this study may be related to an increase in the users' bond with the health service; so that, in order to stimulate adherence to antiretroviral treatment, many health professionals who assist these people, involve families in the treatment of their users, provide social and psychological support to these people ${ }^{(27)}$, which strengthens the family bond and may justify the increase in QoL related to professional confidence.

\section{Study limitations}

Regarding the development of this study, it is noticed that as a limiting factor there is the selection of the participants, although they are part of a convenience sample, the study involved all PLHAs, aged 50 years and older who were in outpatient treatment.

Contributions to the area of nursing, health or public policy

Thus, the results found and studies of this nature, besides the possibility of sensitizing health professionals directly linked to PLHA care, could subsidize health care interventions that will help improve QoL in the different segments of people living with HIV/AIDS, positively impacting the improvement of ART adherence.

\section{CONCLUSION}

The results of this study suggest that quality of life is directly related to the sociodemographic and clinical profile of PLHA, related not only to physical changes but also to HIV/AIDSrelated anxieties and stigma.

The results presented portray the reality of the studied population, due to the scarcity of studies of this nature in the national literature, more studies are investigated that investigate the quality of life in the elderly living with HIV/AIDS in diverse social contexts.

\section{REFERENCES}

1. United Nations. Joint United Nations Program on HIV/AIDS. The Gap Report: a special supplement to the UNAIDS report on the global AIDS epidemic 2014 [Internet]. Geneva, Switzerland: ONU; 2016 [cited 2017 Jun 23]. Available from: http://www.unaids. org/sites/default/files/media_asset/UNAIDS_Gap_report_en.pdf

2. Domingues CS, Waldman EA. Causes of death among people living with SIDA in the pre-and pos-HAART eras in the city of São Paulo, Brazil. PLoS ONE [Internet]. 2014[cited 2017 Jun 23];9(12):1-16. Available from: https://www.ncbi.nlm.nih.gov/pmc/ articles/PMC4263674/pdf/pone.0114661.pdf

3. Gaspar J, Reis RK, Pereira FMV, Neves LAS, Castrighini CC, Gir E. Quality of life in women with HIV/AIDS in a municipality in the State of São Paulo. Rev Esc Enferm USP [Internet]. 2011 [cited 2017 Jun 23];45(1):230-6. Available from: http://www.scielo.br/ pdf/reeusp/v45n1/en_32.pdf 
4. Oliveira FBM, Moura MEB, Araújo TME, Andrade EMLR. Quality of life and associated factors in people living with HIV/AIDS. Acta Paul Enferm [Internet]. 2015[cited 2017 Jun 23];28(6):510-6. Available from: http://www.scielo.br/pdf/ape/v28n6/en_19820194-ape-28-06-0510.pdf

5. Ferreira BE, Oliveira IM, Paniago AMM. Quality of life of people living with HIV/AIDS and its relationship with CD4 + lymphocytes, viral load and time of diagnosis. Rev Bras Epidemiol [Internet]. 2012[cited 2017 Jun 23];15(1):75-84. Available from: http://www. scielo.br/pdf/rbepid/v15n1/07.pdf

6. Okuno MFP, Gomes AC, Meazzini L, Scherrer Jr J, Belasco Jr D, Belasco AGS. Qualidade de vida de pacientes idosos vivendo com HIV/AIDS. Cad Saúde Pública [Internet]. 2014[cited 2017 Jun 23];30(7):1551-9. Available from: http://www.scielo.br/pdf/ csp/v30n7/0102-311X-csp-30-7-1551.pdf

7. Lopes PSD, Silva MMG, Torres IC, Stadñik CMB. Qualidade de vida dos pacientes HIV positivo com mais de 50 anos. Rev AMRIGS [Internet]. 2011[cited 2017 Jun 23];55(4):356-60. Available from: http://pesquisa.bvsalud.org/portal/resource/pt/ biblio-835384?lang $=\mathrm{es}$

8. Soarez PC, Castelo A, Abrão P, Holmes WC, Ciconelli RM. Tradução e validação de um questionário de avaliação de qualidade de vida em Aids no Brasil. Rev Panam Salud Publica [Internet]. 2009[cited 2017 Jun 23];25(1):69-76. Available from: http://iris. paho.org/xmlui/handle/123456789/9886

9. Souza JCF, Silva ACO, Leadebal ODCP, Freitas FFQ, Holmes ES, Albuquerque SGE, et al. Quality of Life Evaluation of Elderly People Living with HIV/AIDS According to HAT-QoL. Int Arch Med: Epidemiol [Internet]. 2016[cited 2017 Jun 23];9(37). Available from: http://imed.pub/ojs/index.php/iam/article/view/1499

10. Nideröst S, Imhof C. HIV aging in the age of antiretroviral treatment: living conditions and quality of life of people over 50 living with HIV / AIDS in Switzerland. Gerontol Geriatr Med [Internet]. 2016[cited 2017 Jun 23];2:2333721416636300. Available from: https://www.ncbi.nlm.nih.gov/pmc/articles/PMC5119792/pdf/10.1177_2333721416636300.pdf

11. Soares GB, Garbin CAS, Rovida TAS, Garbin AJI. Quality of life of people living with HIV/AIDS treated by the specialized service in Vitória-ES, Brazil. Ciênc Saúde Colet [Internet]. 2015[cited 2017 Jun 23];20(4):1075-84. Available from: http://www.scielo.br/ $\mathrm{pdf} / \mathrm{csc} / \mathrm{v} 20 \mathrm{n} 4 / 1413-8123-\mathrm{csc}-20-04-01075 . \mathrm{pdf}$

12. Varaz-Díaz N, Neilands TB, Cintrón-Bou F, Santos-Figueroa A, Rodríguez-Madera S, Santiago-Negrón S. The Role of Gender on HIV/AIDS Stigma among Medical Students in Puerto Rico: implications for training and service delivery. Pto Rico Health Sci J [Internet]. 2012[cited 2017 Jun 23];31(4):220-2. Available from: https://www.ncbi.nlm.nih.gov/pmc/articles/PMC4140944/pdf/ nihms605477.pdf

13. Costa FM, Souza IC, Ribeiro ZS, Santos JAD, Carneiro JA. Mulheres vivendo com HIV/AIDS: avaliação da qualidade de vida. Rev Saúde Pesq [Internet]. 2014 [cited 2017 Jun 23];7(3):503-13. Available from: http://periodicos.unicesumar.edu.br/index.php/ saudpesq/article/view/3667/2493

14. Hipolito RL, Oliveira DC, Gomes AMT, Costa TL. Representações sociais da qualidade de vida no HIV/aids no papel do tempo de diagnóstico. Rev Enferm UERJ [Internet]. 2014[cited 2017 Jun 23];22(6):803-09. Available from: http://www.e-publicacoes.uerj. br/index.php/enfermagemuerj/article/view/12840/12243

15. Cunha GH, Fiuza MLT, Gir E, Aquino PS, Pinheiro AKB, Galvão MTG. Quality of life of men with AIDS and the model of social determinants of health. Rev Latino-Am Enfermagem [Internet]. 2015[cited 2017 Jun 23];23(2):183-91. Available from: http://www. scielo.br/pdf/rlae/v23n2/0104-1169-rlae-23-02-00183.pdf

16. Silva JB, Cardoso GCP, Netto AR, Kritski AL. Os significados da comorbidade para os pacientes vivendo com TB/HIV: repercussões no tratamento. Physis Rev Saúde Colet [Internet]. 2015[cited 2017 Jun 23];25(1):209-29. Available from: http://wwwscielosp.org/ pdf/physis/v25n1/0103-7331-physis-25-01-00209.pdf

17. Alvarenga WA, Silva MR, Nascimento LC, Wernet M, Oliveira FFD, Dupas G. Experience of family members providing care for HIV-exposed children: beginning of the trajectory. Rev Gaúcha Enferm [Internet]. 2014[cited 2017 Jun 23];35(3):68-74. Available from: http://www.scielo.br/pdf/rgenf/v35n3/1983-1447-rgenf-35-03-00068.pdf

18. Reis CBS, Araújo MAL, Andrade RFV, Miranda AEB. Prevalence and factors associated with paternity intention among men living with HIV/AIDS in Fortaleza, Ceará. Texto Contexto Enferm [Internet]. 2015[cited 2017 Jun 23];24(4):1053-60. Available from: http://www.scielo.br/pdf/tce/v24n4/0104-0707-tce-201500003560014.pdf

19. Mora C, Monteiro S, Moreira COF. Formação, práticas e trajetórias de aconselhadores de centros de testagem anti-HIV do Rio de Janeiro, Brasil. Formação, práticas e trajetórias de aconselhadores de centros de testagem anti-HIV do Rio de Janeiro, Brasil. Interface [Internet]. 2015[cited 2017 Jun 23];19(55):1145-56. Available from: http://www.scielo.br/pdf/icse/2015nahead/18075762-icse-1807-576220140609.pdf

20. Schaefer AS, Garcia CV, Rezende DS, Martins DA, Cruz KR, Scherer EF. Mudanças que ocorrem na vida da mulher portadora do HIV/AIDS após o diagnóstico. Interdisciplinar: Rev Eletrôn Univar [Internet]. 2013[cited 2017 Jun 23];1(9):14-6. Available from: http://www.univar.edu.br/revista/index.php/interdisciplinar/article/view/47/38

21. Sousa LMS, Silva LS, Palmeira AT. Representações Sociais de caminhoneiros de rota Curta Sobre HIV / AIDS. Rev Psicol Soc [Internet]. 2014[cited 2017 Jun 23];26(2):346-55. Available from: http://www.redalyc.org/html/3093/309331732011/

22. Mutabazi-Mwesigire D, Katamba A, Martin F, Seeley J, Wu AW. Factors affecting the quality of life among people living with HIV 
Attending an urban clinic in Uganda: a cohort study. PLoS ONE [Internet]. 2015[cited 2017 Jun 23];10(6):e0126810. Available from: http://journals.plos.org/plosone/article?id=10.1371/journal.pone.0126810

23. Passos SMK, Souza LDM. An evaluation of quality of life and its determinants among people living with HIV/AIDS from Southern Brazil. Cad Saúde Pública [Internet]. 2015[cited 2017 Jun 23];31(4):800-14. Available from: http://www.scielo.br/pdf/csp/ v31n4/0102-311X-csp-31-04-00800.pdf

24. Liping M, Peng X, Haijiang L, Lahong J, Fan L. Quality of life of people living with HIV/AIDS. A cross-sectional study in Zhejiang Province, China. PLoS ONE [Internet]. 2015[cited 2017 Jun 23];10(8):e0135705. Available from: https://www.ncbi.nlm.nih.gov/ pmc/ articles /PMC4550400/

25. Pacheco BP, Gomes GC, Xavier DM, Nobre CMG, Aquino DR. Dificuldades e facilidades da família para cuidar a criança com HIV/Aids. Esc Anna Nery Rev Enferm [Internet]. 2016[cited 2017 Jun 23];20(2):378-83. Available from: http://www.scielo.br/pdf/ ean/v20n2/1414-8145-ean-20-02-0378.pdf

26. Luz PM, Bruyand M, Ribeiro S, Bonnet F, Moreira RI, Hessamfar M, et al. Severe morbidity AIDS and non-AIDS associated hospitalizations among HIV-infected patients in two regions with universal access to care and antiretroviral therapy, France and Brazil, 2000-2008: hospital-based cohort studies. BMC Infect Dis [Internet]. 2014[cited 2017 Jun 23];14(278). Available from: http://bmcinfectdis.biomedcentral.com/articles/10.1186/1471-2334-14-278

27. Lourdes BP, Costa PHA, Ronzani TM. As redes sociais no cuidado aos usuários de drogas: revisão sistemática. Psicol Estud [Internet]. 2016[cited 2017 Jun 23];21(1):29-39. Available from: http://periodicos.uem.br/ojs/index.php/PsicolEstud/article/ view/28489/pdf 